\section{The effect of advergames, banners and user type on the attitude to brand and intention to purchase}

\section{Pablo Farías}

Department of Administration, University of Chile, Santiago, Chile

\begin{abstract}
Purpose - This research was intended to analyze the effectiveness of advergames in comparison with banners. In addition, it seeks to analyze whether the type of user (someone who just casually browses the Internet vs. someone looking for product information on the Internet) will influence the effectiveness of both Internet advertising formats.
\end{abstract}

Design/methodology/approach - An experiment with 152 participants controlling perceived entertainment.

Findings - it has been observed that advergames are not superior to banners in improving the attitude towards brand and intention to purchase. These results are independent of the type of user (casual browsers vs. information seekers).

Originality/value - While banners are traditional formats in Internet advertising, other formats have emerged as technology advances, such as advergames.

Keywords - Internet advertising; banners; advergames; casual browsers; information seekers.
Received on

03/15/2017

Approved on

09/07/2017

Responsible editor:

Prof. Dr. Susana Costa e Silva

Evaluation process:

Double Blind Review

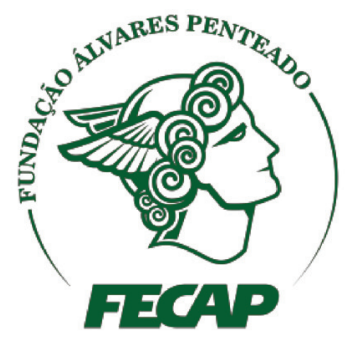

Review of Business Management 


\section{Introduction}

Consumers daily browse the Internet for several hours, being vulnerable and susceptible to advertisements on the web. The target audience of many companies is in this online channel. The Internet has created a new business paradigm that presents companies with remarkable opportunities and challenges. The Internet has raised new questions about the importance of advertising and what could represent effective marketing strategies in this channel (Almeida, Costa, Coelho, \& Scalco, 2016; Hidalgo \& Farías, 2016; Nasir, 2017; Zhang \& Lin, 2014).

In the United States, surpassing seventytwo billion dollars, the Internet is the largest advertising investment channel (Price Waterhouse Coopers, 2017). In Latin America, advertising investment on the Internet is expanding and exceeds eight billion dollars, with Brazil, Mexico and Argentina as the countries with the highest advertising investment on the Internet, and Chile with the highest penetration in this channel. In addition, Latin America has the largest population growth online in comparison with any other region in the world, fueling a boom in e-commerce and Internet advertising (Agostini \& Willington, 2016; eMarketer, 2016; Felizola, Araújo, Nunes, Gomes, \& Menezes, 2017; Souza, Santos, Reis, Freitas, \& Rocha, 2015).

An advertising format that has been widely used on the Internet are banners. In the United States, it is the third largest advertising investment on the Internet (12\% of Internet advertising investment) after mobile advertising and search engine advertising (Price Waterhouse Coopers, 2017). Banners were initially created to direct audiences among different websites, but because of their low proportion of clicks, many companies use them as advertising equivalent to a billboard on a motorway, but in this case on a website (Van Steenburg, 2012). Since most users look at them even if they do not click on them, these banners have a lot of impact on users, and are used as a promotional tool by companies (Hervet, Guérard,
Tremblay, \& Chtourou, 2011; Martín-Santana \& Beerli-Palacio, 2012).

While banner advertisements are traditional forms of advertising on the Internet, other webbased products have emerged as technology advances, such as advergames (advertising and game). This Internet advertising format consists of placing a brand, product, organization or idea in an online game (Çeltek, 2010; Gross, 2010; Lee $\&$ Faber, 2007). An advergame is tailored to the requirements of the advertiser (Bellman, Kemp, Haddad, \& Varan, 2014; Lee \& Youn, 2008; Terlutter \& Capella, 2013). This new format of advertising on the Internet is beginning to be widely used by businesses. Lee, Quilliam and Cole (2009), through a content analysis of the websites of top hundred advertising companies in the United States, showed that twenty-nine of these advertisers had a total of two hundred and ninety-four advergames hosted on their websites.

Advergames are characterized by having a greater interaction with the user in comparison to banners, and therefore, they are expected generate a different response in consumers. However, little is known if this format of advertising on the Internet is more effective than the advertisements in banners. Jung, Min and Kellaris (2011) researched the effectiveness of advergames in comparison to banners, however, research by Jung et al. (2011) focused upon the perceived entertainment of both Internet advertising formats. They manipulated, in their experiment, an advergame in order for it to be more entertaining than a banner, making it difficult to directly compare both Internet advertising formats, as previous research has shown that perceived entertainment improves consumer response (Hernandez, 2008; Kim \& Forsythe, 2009; Martí-Parreño, Aldás-Manzano, Currás-Pérez, \& Sánchez-García, 2013; Zhang \& Mao, 2016).

Therefore, this paper presents a research that seeks to analyze the effectiveness of advergames in comparison to banner advertisements, following the methodology of Jung et al. (2011), but correcting and controlling the bias caused by the 
manipulation of perceived entertainment, and, therefore, manipulating, in the experiment, an advergame with a similar perceived entertainment of a banner. Additionally, and like Jung et al. (2011), it seeks to analyze whether the type of user, i.e., someone who only casually browses the Internet (casual browser) in comparison to someone looking for product information on the Internet (information seeker) will influence the effectiveness of both advertising formats on the Internet.

The remainder of the article is organized as follows: section two presents the conceptual framework; section three presents the methodology followed in this research; section four presents the study results; and section five presents comments on the implications of this research for managers and researchers.

\section{Conceptual framework}

\section{I Advertising formats on the Internet: the effect of advergames and banners}

Most of the studies that have researched banner effectiveness have focused on analyzing the click through rates (CTR) that is calculated as the ratio between the clicks on the banner and the total number of visitors exposed to the banner. These studies show quite disappointing results for banners, showing CTR close to $1 \%$ (Cho, 2003; Dahlen, Rasch, \& Rosengren, 2003; Lohtia, Donthy, \& Hershberger, 2003). However, click through rates are not the only indicator of effectiveness of an Internet advertising format. Even without clicking on the banner, previous research has shown that banners can improve brand recall, improve attitude towards the brand, and increase brand purchase intent (Bayles, 2000; Briggs \& Hollis, 1997; Chiu, Lo, \& Hsieh, 2017; Dreze \& Hussherr, 2003; Obal \& Lv, 2017; Shamdasani, Stanaland, \& Tan, 2001; Yoon \& Lee, 2007).

Advergaming is the practice of creating video games to advertise a brand, product, organization or idea (Kuo \& Rice, 2015). In spite of its recent massification, the origin of the advergames goes back to the 1980s, and, although at first its use was sporadic, it has grown rapidly in recent years as a result of the growth of the video game industry, and the expansion of the number of players, as well as the migration of audiences to digital media (Lee \& Cho, 2017, Mollen \& Wilson, 2010). Indeed, the recent use of advergames by advertising companies is not an isolated phenomenon nor has it suddenly appeared. Advertisements in online games break into Internet advertising thanks to the paradigm shift that media interactivity has brought about. When the user visits a website, they have control over the information flow and can decide what information to see, in which order to view this information, and for how long to see this information (Ariely, 2000; Bellman et al., 2014; Bezjian-Avery, Calder, \& Iacobucci, 1998).

Interactivity on the Internet can be conceptualized as a feature of computermediated communication that increases with dual directionality, punctuality, mutual control and responsiveness of communication according to the perception of users (Yadav \& Varadarajan, 2005; Verberckmoes, Poels, Dens, Herrewijn, \& Pelsmacker, 2016). The level of engagement can be critical in involving Internet users in the communication process (Ghose \& Dou, 1998). At greater interactivity, users perceive greater control over the process of information exchange (Klein, 2003). Interactivity can increase user engagement, user satisfaction, and user differentiation (Liu \& Shrum, 2002; Shih, 1998). However, interactivity requires that the user spend resources (e.g., mental effort, time) in processing and managing the information flow (Ariely, 2000; Eveland \& Dunwoody, 2002). In addition, advertisements in online games could sometimes be ineffective when perceived as annoying by the user (Deal, 2005).

Previous research analyzing different formats of advergames has shown that these positively influence on the attitude toward the brand and the intention to purchase (Kuo \& Rice, 2015; Lin, 2014). Advergames and interactive advertising in general have completely changed 
the current advertising paradigm in traditional advertising formats, going from unidirectionality, i.e., sending the message from a single direction, without immediate response, to bidirectionality, where communication is given in both directions, obtaining immediate responses (Kuo \& Rice, 2015; Lin, 2014; Vashisht \& Royne, 2016; Verberckmoes et al., 2016). Advergames are video games that allow a continuous exposure of the user to the advertised brand, and the user can interact with the brand's values and positioning (Lee \& Cho, 2017). Interactivity can be a fundamental element as it is what enables contact (even if is simulated) with the product that is intended to be promoted. Because an advergame is a more interactive experience than browsing a website with banners (Vashisht \& Royne, 2016; Verberckmoes et al., 2016), brands advertised in advergames should present, in response by consumers, a better attitude towards the brand and a greater intention to purchase the brand than the brands advertised in banners. Therefore:

H1. Consumers have a better attitude towards the brand and (b) intention to purchase when exposed to advergames than when exposed to banners.

\subsection{Type of user on the Internet: casual browsers and information seekers}

Several studies show that the effectiveness of Internet advertising is influenced by the type of user on the Internet (e.g., Cicchirillo \& Mabry, 2016; Gauzente, 2010; Hsieh \& Chen, 2011; Möller \& Eisend, 2010). Schlosser (2003) shows that consumer attitudes are influenced by the congruence between their objectives and experience in the context of virtual interaction with a product. Users are likely to develop positive attitudes towards the brand if they discover that the product information in the advertisement is of great help in meeting their goals.

On the Internet, users can be information seekers or casual browsers (Kim \& Forsythe,
2008; Moe, 2003). Information seekers look for product data, and casual browsers do not. Casual browsers tend to focus on having an entertaining web experience, and information seekers tend to focus on how much product information they can get on the web (Gupta, Nadkarni, \& Gould, 2005; Shim, Eastlick, Lotz, \& Warrington, 2001; Sivaramakrishnan, Wan, \& Tang, 2007). Schlosser (2003) shows that, when information is passively delivered (e.g., through banners), information seekers perform more elaborate processing and form more positive attitudes toward the brand compared to casual browsers. In contrast, when information is presented in a more interactive way (e.g., through advergames), casual browsers (vs. information seekers) use more heuristic processing and form more positive attitudes toward the brand compared to information seekers. Jung et al. (2011) noted that the advantage for advergames as a product of perceived entertainment increases for casual browsers. Therefore:

H2. For advertisements in banners (advergames), information seekers present a better (worse) (a) attitude towards the brand and (b) intention to purchase than casual browsers.

\section{Research design}

Following the methodology used by Jung et al. (2011) to check the hypotheses proposed in this research, we used a factorial design between subjects of 2 (Internet advertising format: banner vs. advergame) x 2 (type of user on the Internet: casual browsers vs. information seekers).

This research aimed to evaluate the effectiveness of both Internet advertising formats, measuring the attitude towards the brand and the intention to purchase the brand of participants exposed to advertisement inserted in an advergame vs. advertisement inserted in a banner. Advertisements were developed with similar entertainment both in the banner and in the advergame, because several studies suggest that the perceived entertainment influences positively 
on the effectiveness of Internet advertising formats (Hernandez, 2008; Kim \& Forsythe, 2009; MartíParreño et al., 2013; Zhang \& Mao, 2016).

Figures 1 and 2 present the stimuli developed and used in this research. The banner developed is animated and uses the Chilean beer brand Becker. Figure 1 presents the animated banner developed and used in the experiment. The animated banner was placed at the top of a music website, tuned for studio participants. Figure 2 presents the advergame developed and used in the experiment. The advergame developed is illustrative, and includes an activity in which each participant must match various images associated with the Chilean beer brand Becker. This beer brand belongs to Cervecería Chile, which is a company belonging to ABInbev, the largest brewery group in the world. This group has more than two hundred brands globally, where four of them are among the ten best-selling beer brands in the world.

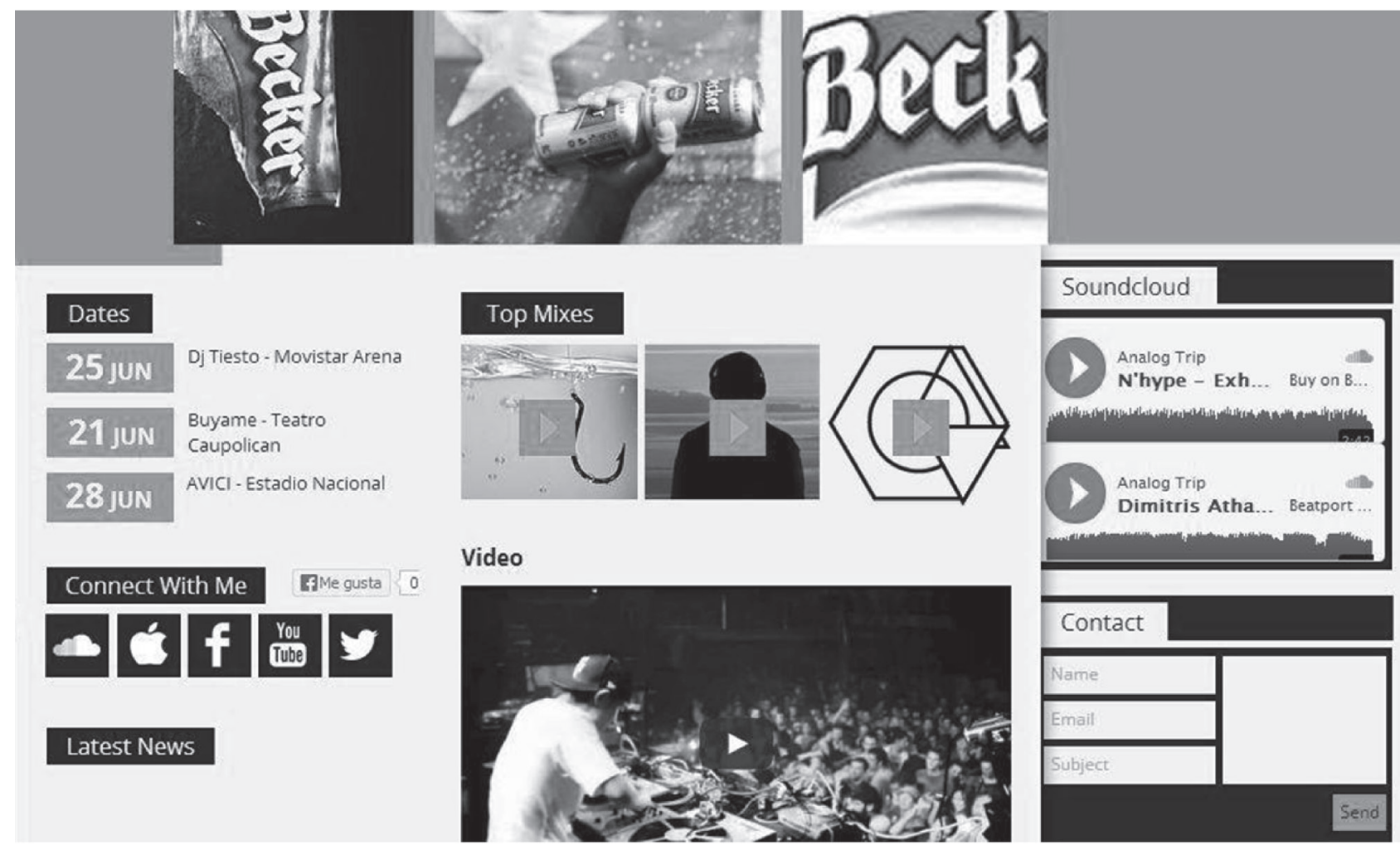

Figure 1. Banner used in this experiment. 


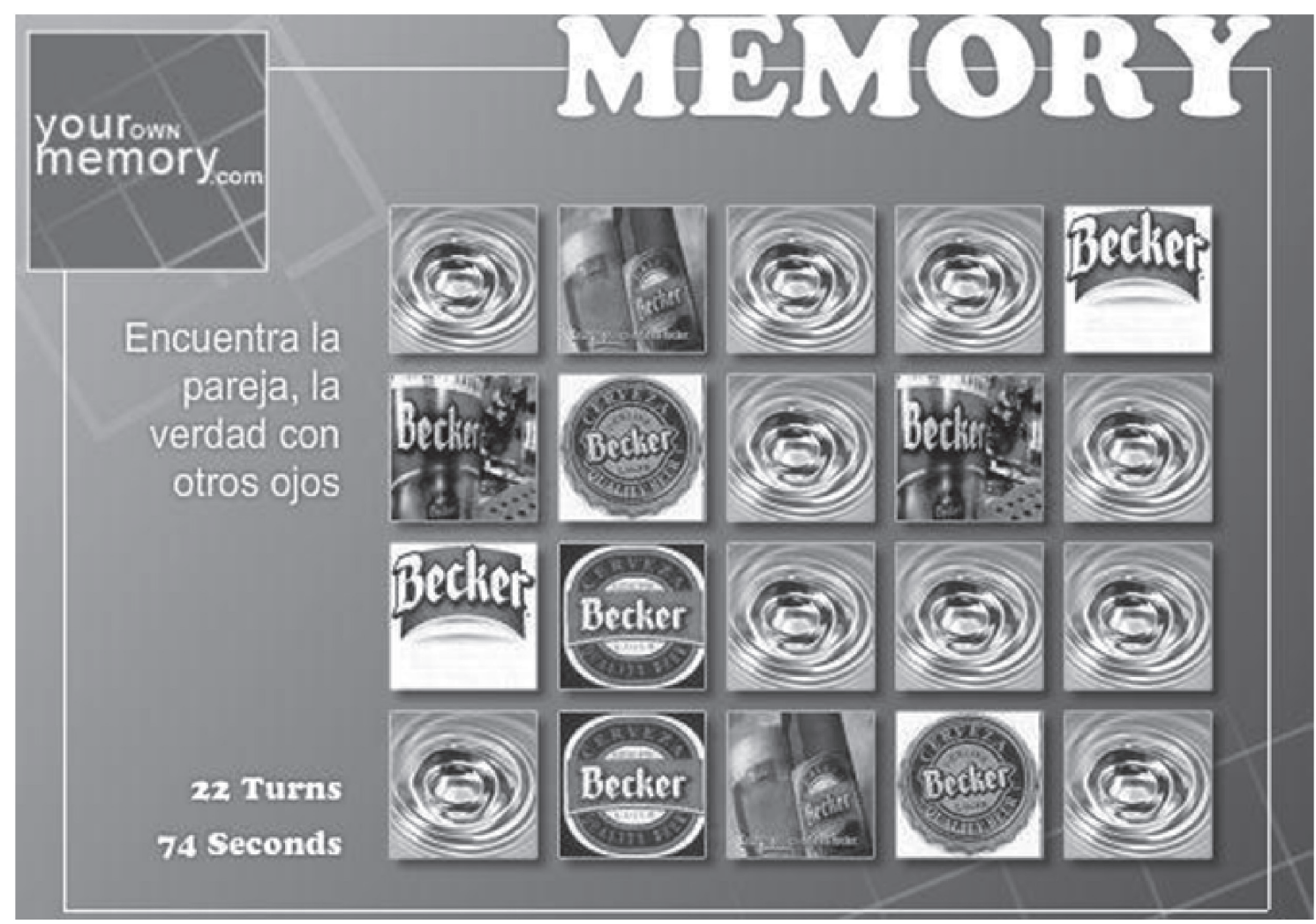

Figure 2. Advergame used in this experiment.

One hundred and fifty-two undergraduate students from a major university located in the city of Santiago de Chile participated in this experiment. Samples of undergraduate students have been widely used in research related to examining the effectiveness of advertising formats both on the Internet and in traditional media, such as radio, television, newspapers and magazines (Choi \& Miracle, 2004; Farías, 2015; Jung et al., 2011; Manzur, Uribe, Hidalg, Olavarrieta, \& Farías, 2012; Pillai \& Goldsmith, 2008; Yagci, Biswas, \& Dutta, 2009). Previous studies have stated that the use of homogeneous convenience samples improves the internal validity of experimental results (Calder, Phillips, \& Tybout, 1981; Cook \& Campbell, 1976).

Additionally, a sample of undergraduate students was appropriate for the present experiment because undergraduates have been, are, and will be an important target market for a large number of companies in a significant number of product categories (e.g., beer, fantasy beverages, cell phone, banking, electronics, computing, clothing, entertainment). In Chile and in the rest of the world, companies that sell this type of products have carried out promotional campaigns directed directly at this market segment (Farías \& Fistrovic, 2016).

Participants were randomly assigned to one of four treatments $(2 \times 2$, two internet advertising formats vs. two types of users on the Internet). Prior to exposure to the advertisements (banner or advergame), a group of participants were instructed to imagine needing to buy beer for a party in the next few days. 81 participants are classified as information seekers. The rest of the participants in the experiment were not provided with this information. 71 participants are classified as casual browsers. Seventy-six participants in the experiment were asked to browse the music website that included the banner presented in Figure 1 for five minutes and the other 76 participants in the experiment were asked to participate in the advergame presented 
in Figure 2 for five minutes. Subsequently, all participants in the experiment were given the same questionnaire format. As a consequence, 37 participants received the advergame and, at the same time, they were classified as casual browsers, 39 participants received the advergame, and were classified as information seekers, 34 participants received the banner, and were classified as casual browsers, and 42 participants received the banner, and were classified as information seekers.

The following constructs were measured in this questionnaire: perceived entertainment (this construct was used to check the manipulation of advertisements developed and used in this experiment), attitude toward the brand and the intention to purchase the brand. These constructs are commonly used to measure consumer response, and thus advertisement effectiveness (e.g., Manzur et al., 2012; White Nye, Roth, \& Shimp, 2008; Yagci et al., 2009). Each of these constructs was measured following the methodology used and presented by Jung et al. (2011). The scales used to measure these constructs are presented in the Attachment.

\section{Results}

The two multi-item scales used showed high internal consistency with Cronbach's alphas of .70 (Nunnally, 1978). The perceived entertainment scale featured a Cronbach alpha of .79, and the attitude scale towards the brand featured a Cronbach alpha of .89. The checking of alert manipulation shows that both advertisements do not differ in the entertainment perceived by participants in the laboratory experiment $\left(\mathrm{M}_{\text {banner }}=4.87\right.$ and $\mathrm{M}_{\text {advergame }}=5.05$; valor $\mathrm{p}>0.1)$. Therefore, it can be concluded that the manipulation was successful by observing that both stimuli used in the experiment did not differ in the level of perceived entertainment.

Analysis of variance (ANOVA) was used by Jung et al. (2011), and has been widely used by other researchers in the analysis of the effectiveness of advertising formats (e.g., Barone, Palan, \& Miniard, 2004; Farías, 2015; Manzur et al., 2012; Priester, Godek, Nayakankuppum, \& Park, 2004; White Nye et al., 2008; Yagci et al., 2009). Consequently, ANOVA 2 (Internet advertising format: advergame vs. banner) x 2 (user type on the Internet: casual browsers vs. information seekers) was performed on dependent variables "attitude towards the brand" (calculated as the simple average of the 4 items used to measure this construct) and "intention to purchase the brand" (scale of an item used to measure this construct) to examine hypotheses 1 and 2 presented in this research.

Table 1

Averages in the four treatments used in this experiment

\begin{tabular}{|c|c|c|c|c|c|}
\hline & $\begin{array}{c}\text { Advergame } \\
\text { and casual browsers } \\
(\mathrm{N}=37)\end{array}$ & $\begin{array}{c}\text { Advergame } \\
\text { and information } \\
\text { seekers } \\
(\mathrm{N}=39)\end{array}$ & $\begin{array}{l}\text { Banner } \\
\text { and casual } \\
\text { browsers } \\
(\mathrm{N}=34)\end{array}$ & $\begin{array}{c}\text { Banner } \\
\text { and information } \\
\text { seekers } \\
(\mathrm{N}=42)\end{array}$ & $\begin{array}{l}\text { F value } \\
\text { ( } p \text { value) }\end{array}$ \\
\hline $\begin{array}{l}\text { Attitude towards the } \\
\text { brand }\end{array}$ & 5.09 & 4.94 & 4.78 & 5.10 & $\begin{array}{l}.626 \\
(.599)\end{array}$ \\
\hline $\begin{array}{l}\text { Intention to purchase } \\
\text { the brand }\end{array}$ & 4.54 & 4.38 & 4.35 & 4.43 & $\begin{array}{c}.929 \\
(.428)\end{array}$ \\
\hline
\end{tabular}


Table 1 shows the average in the four treatments used in this experiment for dependent variables attitude towards the brand and intention to purchase the brand. No statistically significant differences were observed in both dependent variables among the four treatments ( $\mathrm{p}$ values> 0.1 ). Table 2 shows the ANOVAs performed for each of these dependent variables and $\mathrm{Eta}^{2}$ which reflect the percentage (proportion) of the variance of the dependent variable explained by the independent variable in the sample data. Hypotheses $\mathrm{H} 1 \mathrm{a}$ and $\mathrm{H} 1 \mathrm{~b}$ are not supported because there is no significant effect of the type of Internet advertising format (advergame vs. banner) on the attitude toward the brand and the intention to purchase the brand (see Table 2; p values $>0.1$, greater $\mathrm{Eta}^{2}=.006$ ). Indeed, results show that the attitude towards the brand does not differ between banners $\left(\mathrm{M}_{\text {banner }}=4.94\right)$ and advergames $\left(M_{\text {advergame }}=5.01\right)$. Also, results show that the intention to purchase the brand does not differ between banners $\left(\mathrm{M}_{\text {banner }}=4.39\right)$ and advergames $\left(M_{\text {advergame }}=4.46\right)$.

Table 2

\section{ANOVAs 2 (Advertising formats on the Internet: Advergame vs. Banner) x 2 (Type of user on the Internet: casual browsers vs. Information seekers)}

\begin{tabular}{|c|c|c|c|}
\hline \multicolumn{4}{|l|}{ Panel A: Attitude towards the brand } \\
\hline & F value & p value & $\mathrm{Eta}^{2}$ \\
\hline Advertising format on the Internet: Advergame vs. Banner (H1a) & .162 & .688 & .001 \\
\hline $\begin{array}{l}\text { Type of user on the Internet: Casual browsers } \\
\text { Vs. information seekers }\end{array}$ & .196 & .659 & .001 \\
\hline $\begin{array}{l}\text { Interaction effect between the advertising format on the Internet and } \\
\text { Type of user on the Internet }(\mathrm{H} 2 \mathrm{a})\end{array}$ & 1.597 & .208 & .011 \\
\hline \multicolumn{4}{|l|}{ Panel B: Intention to purchase the brand } \\
\hline & F value & p value & Eta2 \\
\hline Advertising format on the Internet: Advergame vs. Banner (H1b) & .899 & .345 & .006 \\
\hline $\begin{array}{l}\text { Type of user on the Internet: Casual browsers } \\
\text { Vs. information seekers }\end{array}$ & .659 & .418 & .004 \\
\hline $\begin{array}{l}\text { Interaction effect between the advertising format on the Internet and } \\
\text { Type of user on the Internet (H2b) }\end{array}$ & 1.293 & .257 & .009 \\
\hline
\end{tabular}

Note: $\mathrm{Eta}^{2}$ reflects the percentage (proportion) of the variance of the dependent variable explained by the independent variable in the sample data.

The interaction effect between the advertising format on the Internet and the type of user on the Internet (casual browsers vs. information seekers) was not statistically significant (see Table 2, p values $>0.1$, higher $\left.\operatorname{Eta}^{2}=.011\right)$ for both the effect on the attitude towards the brand and the intention to purchase the brand. Therefore, the hypotheses H2a and $\mathrm{H} 2 \mathrm{~b}$ are not supported, since the effect of the advertising format on the Internet depends on the type of user (casual browser vs. information seekers).
The results obtained in this research suggest that advergames alone are not superior to the advertisements included in banners. These results are independent if the user's goal is to seek information on the Internet or just browse it casually. These results differ from those found by Jung et al. (2011), who showed that advergames were more effective than banners. However, research by Jung et al. (2011) focused upon the perceived entertainment of both advertising formats on the Internet (manipulating in the experiment an advergame 
that was more entertaining than a banner), hindering the direct comparison between both advertising formats on the Internet. In contrast, the research presented in this article analyzes the effectiveness of advergames in comparison to the advertisements included in banners, following the methodology developed and presented by Jung et al. (2011), but correcting and controlling the bias caused by the manipulation of perceived entertainment (successfully manipulating in the experiment an advergame with a similar perceived entertainment of a banner). This research shows that, by controlling perceived entertainment, both Internet advertising formats are equally effective and that these results do not depend on the type of user on the Internet (casual browsers vs. information seekers).

\section{Discussion}

Previous research analyzing different banner formats has shown that they positively influence the recall of a brand, the attitude towards the brand and the intention to purchase such brand (Bayles, 2000; Briggs \& Hollis, 1997; Chiu et al., 2017; Dreze \& Hussherr, 2003; Obal \& Lv, 2017; Shamdasani et al., 2001; Yoon \& Lee, 2007). Likewise, previous research analyzing different advergame formats has shown that they positively influence the attitude towards the brand and the intention to purchase the brand (Kuo \& Rice, 2015; Lin, 2014). Unfortunately, little is known about which format is more effective in connection with consumer response.

Jung et al. (2011) observed that advergames are more effective compared to banners in generating attitude towards the brand and purchase intention. However, the research carried out by Jung et al. (2011) focused upon the perceived entertainment of both formats, because they manipulated in the experiment an advergame so it was more entertaining than a banner, making it difficult to directly compare both formats. Previous research has shown that perceived entertainment improves consumer response (Hernandez, 2008; Kim \& Forsythe,
2009; Martí-Parreño et al., 2013; Zhang \& Mao, 2016).

As a consequence, this paper presented a research that analyzed the effectiveness of advergames in comparison to advertisements in banners, following the methodology of Jung et al. (2011), but correcting and controlling the bias caused by the manipulation of perceived entertainment, and therefore manipulating in the experiment an advergame with a similar perceived entertainment of a banner. While only one experiment is not enough to establish the generalized non-superiority of advergames over banners, this study supports the idea that advergames are not necessarily superior to the more traditional and widely used Internet advertising formats as are the advertisements included in banners.

Jung et al. (2011) noted that the advantage for advergames as a product of perceived entertainment increases for casual browsers. In this study, by keeping the perceived entertainment between advergames and banners constant, it was possible to observe that the effectiveness of both formats does not depend on the type of user if both formats have similar perceived entertainment.

\section{I Implications to managers}

The results do not support the belief on the part of some advertising companies that more modern and less traditional formats as the advergames alone exceed more traditional formats of Internet advertising such as advertisements included in banners. These results suggest that advertisers need to carefully evaluate the effectiveness of the advertisements they are going to use in their Internet marketing campaigns.

We recommend that advertising companies should test samples from their target markets of Internet advertising formats created (before launching) in order to anticipate user reactions to Internet advertising formats in order to take corrective actions over time. As per this study, advertisers can test different advergames, 
banners, etc. created, and evaluate the response of consumers by subsequently measuring exposure to these stimuli, the attitude towards the brand, the intention to purchase the brand, etc.

To create advergames, banners, etc., successful results of this study suggest generating them with a high level of perceived entertainment for the target market. One way to ensure the power to create an entertaining advertisement is to inquire, during this creative process through exploratory research, for example using focus groups, ethnography in the target market, etc., about the factors that generate the greater perceived entertainment for the target market to define the themes addressed in the advertisement, the colors to use, the type and the images to include in the advertisement, whether or not to include a celebrity in the advertisement, etc.

It is interesting to note that, more than the advertising format on the Internet (advergame or banner), perceived entertainment is more important to generate a favorable response from consumers. Because advergames tend to be more expensive to create than banners, companies (especially low-budget ones) may elect to create entertaining banners for the target market, which could be more effective than little entertaining advergames. That is, more than the advertising format used on the Internet, companies are suggested to monitor the perceived entertainment of their advertisements on the Internet.

\subsection{Theoretical implications}

This study analyzed the effectiveness of advertising in advergames compared to banners, using as measures of advertising effectiveness the attitude towards the brand and the intention to purchase the brand. Direct comparison of different advertising formats on the Internet (vs. analyzing them individually) can help explain the differences and similarities in achieving the effectiveness of advertising in this channel and underlines the importance of the different formats of Internet advertising in the study of advertising in this channel. The results of this study support the idea that advergames are not necessarily superior to a more traditional and widely used advertising format on the Internet as are the advertisements included in banners.

The biggest reason for this low difference between both advertising formats on the Internet was that participants experienced similar perceived entertainment in both formats. Perceived entertainment improves consumer response (Hernandez, 2008; Kim \& Forsythe, 2009; Martí-Parreño et al., 2013; Zhang \& Mao, 2016). This article contributes to the literature by showing that, if banners and advergames exhibit similar perceived entertainment, there is no difference in consumer response. When presenting advergames and banners with a similar perceived entertainment, differences in the responses from casual browsers and the information seekers are not observed either. Therefore, when constructing theory on processing of advertising formats on the Internet, perceived entertainment must be recognized as playing an important role in response from consumers to those formats.

The interactive nature of advergames could distinguish them from other more traditional formats such as banners. However, it is unclear how relevant this difference in consumer response is. Bellman et al. (2014) propose and show that the interactivity of advergames (vs. a television advertisement) does not necessarily generate a better response from consumers. Therefore, the results of this study also suggest that the role of the interactive nature of new advertising formats on the Internet on consumer response could be less than expected.

\section{$5 \cdot 3$ Limitations and future research}

Although a sample of students helps improve the internal validity of the results due to the high sample homogeneity, future research should use more representative samples of the population in order to ensure the external validity of the results presented in this research. While using a sample of undergraduate students was appropriate for this research, future studies should 
also use samples of consumers that may be target markets for many other product categories (e.g., life insurance, pension funds). Such studies could increase the generalization of the results, as well as their application to public policies (regulation) and management in Internet advertising.

Future research can analyze the potential impact of consumer characteristics on the effect of advertising formats on the Internet. Not all individuals are equal, therefore, individual differences, such as consumer engagement, consumer experience, brand loyalty, etc., can be incorporated into future research analyzing the effect of Internet advertising formats on consumer response (Farías, 2017; Manzur, Olavarrieta, Hidalgo, Farías, \& Uribe, 2011).

Using in an experiment only one advergame and only one banner certainly is not enough to establish a definitive set of conclusions. Further research could include a greater variety of banners (e.g., static, rotating) and advergames (e.g., associative, demonstrative). Also, this study must be replicated with other brands or even with fictitious brands (to avoid the effects of the brand).

Future research may also evaluate other online advertising formats (e.g., online videos), other brands (e.g., well-known vs. ill-known brands), and types of product categories (e.g., high engagement vs. low engagement, hedonic products vs. functional products).

An interesting question not addressed in this paper is the advergame difficulty for the user. It would be interesting to investigate how the difficulty in advergames influences the attitude towards the brand and the intention to purchase the brand, and therefore, the effectiveness of both online advertising formats.

Another outstanding question is to analyze the effectiveness of both advertising formats on the Internet in the short (days), medium (weeks, months) and long term (years), i.e., analyze the effectiveness of both formats when the user visits several times the website (or several websites), and therefore receives the same, similar or combined (e.g., banners and advergames at the same time) stimuli repeatedly over time (Breuer, Brettel, \& Engelen, 2011).

A consumer may be in contact with the brand advertised in an advergame for many hours and days. Therefore, future research can analyze the time of use of the advergame and its potential impact on the effectiveness of advergames and consumer well-being.

The distribution channels of advergames are diverse. Advertiser can distribute their advergames totally free through the Internet (on their own website or on websites that collect games), via email directly to their current and potential customers, in different application stores, through mobile phones, social networks, etc. Similar is the case for banners, which may have a different response depending on the website in which the banner is inserted (Auschaitrakul \& Mukherjee, 2017). Therefore, another research question might be to analyze the result of using these different distribution channels in the effect of advergames and banners on consumer response.

Possible differences between countries make it essential to conduct studies that measure and compare the different effects of Internet advertising formats on the response of consumers from different countries. Therefore, future research can confirm or refute the results found in this research in other countries. We recommend that these studies should include countries with different levels of development (emerging and developed countries; Wang \& Sun, 2010), Internet penetration and cultural dimensions (Farías, 2016; Hofstede, 2001) to observe if these variables can affect the response from consumers to different formats of advertising on the Internet.

\section{References}

Almeida, M. I. S., Costa, M., Coelho, R. L. F., \& Scalco, P. R. (2016). "Engage and attract me, then I'll share you": An analysis of the impact of post category on viral marketing in a social networking site. Revista Brasileira de Gestão de Negócios, 18(62), 545-569. 
Agostini, C. A., \& Willington, M. (2016). Acceso y uso de internet en Chile: Evolución y factores determinantes. Persona y sociedad, 26(1), 11-42.

Ariely, D. (2000). Controlling the information flow: Effects on consumers' decision making and preferences. Journal of Consumer Research, 27(2), 233-248.

Auschaitrakul, S., \& Mukherjee, A. (2017). Online display advertising: The influence of web site type on advertising effectiveness. Psychology \& Marketing, 34(4), 463-480.

Barone, M., Palan, K., \& Miniard, P. (2004). Brand usage and gender as moderators of the potential deception associated with partial comparative advertising, Journal of Advertising, 33(1), 19-28.

Bayles, M. (2000). Just how 'blind' are we to advertising banners on the web? Usability news, $2,1-7$.

Bellman, S., Kemp, A., Haddad, H., \& Varan, D. (2014). The effectiveness of advergames compared to television commercials and interactive commercials featuring advergames. Computers in Human Behavior, 32, 276-283.

Bezjian-Avery, A., Calder, B., \& Iacobucci, D. (1998). New media interactive advertising vs. traditional advertising. Journal of Advertising Research, 38(4), 23-32.

Breuer, R., Brettel, M., \& Engelen, A. (2011), Incorporating long-term effects in determining the effectiveness of different types of online advertising. Marketing Letters, 22(4), 327-340.

Briggs, R., \& Hollis, N. (1997). Advertising on the Web: Is there response before click through? Journal of Advertising Research, 37(2), 33-45.

Calder, B., Phillips, L. \& Tybout, A. (1981). Designing research for application. Journal of Consumer Research, 8(2), 197-207.
Çeltek, A. (2010). Mobile advergames in tourism marketing. Journal of Vacation Marketing, 16(4), 267-281.

Chiu, Y. P., Lo, S. K., \& Hsieh, A. Y. (2017). How colour similarity can make banner advertising effective: Insights from Gestalt theory. Behaviour \& Information Technology, 36(6), 606-619.

Cho, C. H. (2003). Factors influencing clicking of banner ads on the. Cyber Psychology \& Behavior, 6(2), 201-215.

Choi, Y. K. \& Miracle, G. E. (2004). The effectiveness of comparative advertising in Korea and the United States: a cross-cultural and individual-level analysis. Journal of Advertising, 33(4), 75-87.

Cicchirillo, V., \& Mabry, A. (2016). Advergaming and healthy eating involvement: How healthy eating inclinations impact processing of advergame content. Internet Research, 26(3), 587-603.

Cook, T. D., \& Campbell, D. T. (1976). The design and conduct of true experiments and quasiexperiments in field settings. In M. D. Dunnette (Ed.), Handbook of Industrial and Organizational Psychology (pp. 223-326). Chicago: Rand McNally College Pub. Co.

Dahlen, M., Rasch, A., \& Rosengren, S. (2003). Love at first site? A study of website advertising effectiveness. Journal of Advertising Research, 43(1), 25-33.

Deal, D. (2005). The ability of branded online games to build brand equity: An exploratory study. Proceedings of DiGRA 2005 Conference: Changing Views - Worlds in Play, Vancouver, CA.

Dreze, X., \& Hussherr, F. X. (2003). Internet advertising: Is anybody watching? Journal of Interactive Marketing, 17(4), 8-23.

Eveland, W. P. \& Dunwoody, S. (2002). An investigation of elaboration and selective scanning 
as mediators of learning from the web versus print. Journal of Broadcasting and Electronic Media, 46(1), 34-53.

eMarketer. (2016, March 29). Mobile grabs more digital ad spending in Latin America. Retrieved from https://www.emarketer.com/Article/ Mobile-Grabs-More-Digital-Ad-Spending-LatinAmerica/1013759

Farías, P. (2015). La efectividad de la publicidad oposicional. Estudios Gerenciales, 31(134), 3-7.

Farías, P. (2016). Medición y representación gráfica de las distancias culturales entre países latinoamericanos. Convergencia Revista de Ciencias Sociales, 23(70), 115-141.

Farías, P. (2017). Determinants of perceived and actual knowledge of commission paid by contributors in the pension funds industry. $B R Q$ Business Research Quarterly, 20(1), 18-27.

Farias, P., \& Fistrovic, B. (2016). Consumer preferences using the maximum difference method. Revista de Administração de Empresas, 56(2), 138-151.

Felizola, M. P. M., Araújo, N. A., Nunes, M. C. S., Gomes, V. J. B. M., \& Menezes, M. W. M. (2017). O nordeste conectado: Um quadro do acesso às tecnologias digitais de comunicação pelos jovens. Fronteiras-estudos midiáticos, 19(1), 120-128.

Gauzente, C. (2010). The intention to click on sponsored ads-A study of the role of prior knowledge and of consumer profile. Journal of Retailing and Consumer Services, 17(6), 457-463.

Ghose, S., \& Dou, W. (1998). Interactive functions and their impacts on the appeal of internet presence sites. Journal of Advertising Research, 38(2), 29-43.

Gross, M. (2010). Advergames and the effects of game-product congruity. Computers in Human Behavior, 26(6), 1259-1265.
Gupta, R., Nadkarni, S., \& Gould, S. J. (2005). "Is this site confusing or interesting?" A perceived web site complexity (PWC) scale for assessing consumer internet interactivity. Advances in Consumer Research, 32(1), 42-50.

Hernandez, M. D. (2008). Determinants of children's attitudes towards "advergames": The case of Mexico. Young Consumers, 9(2), 112-120.

Hervet, G., Guérard, K., Tremblay, S., \& Chtourou, M. S. (2011). Is banner blindness genuine? Eye tracking internet text advertising. Applied Cognitive Psychology, 25(5), 708-716.

Hidalgo, P., \& Farías, P. (2016). Use of facebook and the formation and maintenance of social capital: Evidence from Latin America. In M. D. Groza, \& C. B. Ragland (Eds.), Marketing challenges in a turbulent business environment (pp. 701-710). Switzerland: Springer International Publishing.

Hofstede, G. (2001). Culture's Consequences: Comparing Values. Behaviours Institutions and Organizations across Nations (2nd ed.). Thousand Oaks, CA: Sage Publications Inc.

Hsieh, Y., \& Chen, K. (2011). How different information types affect viewer's attention on internet advertising. Computers in Human Behavior, 27(2), 935-945.

Jung, J. M., Min, K. S., \& Kellaris, J. J. (2011). The games people play: How the entertainment value of online ads helps or harms persuasion. Psychology and Marketing, 28(7), 661-681.

Kim, J., \& Forsythe, S. (2008). Adoption of virtual try-on technology for online apparel shopping. Journal of Interactive Marketing, 22(2), 45-59.

Kim, J., \& Forsythe, S. (2009). Adoption of sensory enabling technology for online apparel shopping. European Journal of Marketing, 43(9), 1101-1120. 
Klein, L. R. (2003). Creating virtual product experiences: The role of telepresence. Journal of Interactive Marketing, 17(1), 41-55.

Kuo, A., \& Rice, D. H. (2015). Catch and shoot: The influence of advergame mechanics on preference formation. Psychology \& Marketing, 32(2), 162-172.

Lee, H., \& Cho, C. H. (2017). An application of brand personality to advergames: The effect of company attributes on advergame personality. Computers in Human Behavior, 69, 235-245.

Lee, M., Choi, Y., Quilliam, E., \& Cole, R. (2009). Playing with food: Content analysis of food advergames. Journal of Consumer Affairs, 43(1), 129-154.

Lee, M., \& Faber, R. J. (2007). Effects of product placement in on-line games on brand memory. Journal of Advertising, 36(4), 75-90.

Lee, M., \& Youn, S. (2008). Leading national advertisers' uses of advergames. Journal of Current Issues and Research in Advertising, 30(2), 1-13.

Lin, H. F. (2014). The effect of product placement on persuasion for mobile phone games. International Journal of Advertising, 33(1), 37-60.

Liu, Y., \& Shrum, L. J. (2002). What is interactivity and is it always such a good thing? Implications of definition, person, and situation for the influence of interactivity on advertising effectiveness. Journal of Advertising, 31(4), 53-64.

Lohtia, R., Donthy, N., \& Hershberger, E. K. (2003). The impact of content and design elements on banner advertising click-through rates. Journal of Advertising Research, 43(4), 410418.

Manzur, E., Olavarrieta, S., Hidalgo, P., Farías, P., \& Uribe, R. (2011). Store brand and national brand promotion attitudes antecedents. Journal of Business Research, 64(3), 286-291.
Manzur, E., Uribe, R., Hidalgo, P., Olavarrieta, S., \& Farías, P. (2012). Comparative advertising effectiveness in Latin America: Evidence from Chile. International Marketing Review, 29(3), 277-298.

Martí-Parreño, J., Aldás-Manzano, J., CurrásPérez, R., \& Sánchez-García, I. (2013). Factors contributing brand attitude in advergames: Entertainment and irritation. Journal of Brand Management, 20(5), 374-388.

Martín-Santana, J., \& Beerli-Palacio, A. (2012). The effectiveness of web ads: rectangle vs contextual banners. Online Information Review, 36(3), 420-441.

Moe, W. (2003). Buying, searching, or browsing: Differentiating between online shoppers using in-store navigational clickstream. Journal of Consumer Psychology, 13(1), 29-39.

Mollen, A., \& Wilson, H. (2010). Engagement, telepresence and interactivity in online consumer experience: Reconciling scholastic and managerial perspectives. Journal of Business Research, 63(9), 919-925.

Möller, J., \& Eisend, M. (2010). A global investigation into the cultural and individual antecedents of banner advertising effectiveness. Journal of International Marketing, 18(2), 80-98.

Nasir, V. A. (2017). Identification of web user segments based on beliefs about online ads. Journal of Internet Commerce, 16(3), 1-24.

Nunnally, J. (1978). Psychometric theory (2nd ed.). New York, NY: McGraw-Hill Publishers.

Obal, M. W., \& Lv, W. (2017). Improving banner ad strategies through predictive modeling. Journal of Research in Interactive Marketing, 11(2), 198212.

Pillai, K., \& Goldsmith, R. (2008). How brand attribute typicality and consumer commitment 
moderate the influence of comparative advertising. Journal of Business Research, 61(9), 933-941.

Price Waterhouse Coopers (2017). IAB internet advertising revenue report: 2016 full year results. internet advertising bureau. Retrieved from https:// www.iab.com/wp-content/uploads/2016/04/ IAB_Internet_Advertising_Revenue_Report_ FY_2016.pdf

Priester, J. R., Godek, J., Nayakankuppum, D. J., \& Park, K. (2004). Brand congruity and comparative advertising: When and why comparative advertisements lead to greater elaboration. Journal of Consumer Psychology, 14(1/2), 115-123.

Schlosser, A. E. (2003). Experiencing products in the virtual world: The role of goal and imagery in influencing attitudes versus purchase intentions. Journal of Consumer Research, 30(2), 184-198.

Shamdasani, P. N., Stanaland, A. J., \& Tan, J. (2001). Location, location, location: Insights for advertising placement on the web. Journal of Advertising Research, 41(4), 7-21.

Shih, C. F. (1998). Conceptualizing consumer experiences in cyberspace. European Journal of Marketing, 32(7/8), 655-665.

Shim, S., Eastlick, M., Lotz, S., \& Warrington, P. (2001). An online prepurchase intentions model: The role of intention to search: Best Overall Paper Award-The Sixth Triennial AMS/ACRA Retailing Conference, 2000. Journal of Retailing, 77(3), 397-416.

Sivaramakrishnan, S., Wan, F., \& Tang, Z. (2007). Giving an "e-human touch" to e-tailing: The moderating roles of static information quantity and consumption motive in the effectiveness of an anthropomorphic information agent. Journal of Interactive Marketing, 21(1), 60-75.

Souza, L. A. C., Santos, G. S., Reis, V. M. C. P., Freitas, R. F., \& Rocha, J. S. B. (2015). Tendências da audiência dos meios de comunicação observadas através da nova geração consumidora de informação. Conexâo ciência, 8(2), 37-51.
Terlutter R., \& Capella, M. (2013). The gamification of advertising: Analysis and research directions of in-game advertising, advergames, and advertising in social network games. Journal of Advertising, 42(2), 95-112.

Van Steenburg, E. (2012). Consumer recall of brand versus product banner ads. Journal of Product \& Brand Management, 21(6), 452-464.

Vashisht, D., \& Royne, M. B. (2016). Advergame speed influence and brand recall: The moderating effects of brand placement strength and gamers' persuasion knowledge. Computers in Human Behavior, 63, 162-169.

Verberckmoes, S., Poels, K., Dens, N., Herrewijn, L., \& De Pelsmacker, P. (2016). When and why is perceived congruity important for in-game advertising in fantasy games? Computers in Human Behavior, 64, 871-880.

Wang, Y., \& Sun, S. (2010). Modeling online advertising: A cross-cultural comparison between China and Romania. Journal of Marketing Communications, 16(5), 271-285.

White Nye, C., Roth, M., \& Shimp, T. (2008). Comparative advertising in markets where brands and comparative advertising are novel. Journal of International Business Studies, 39(5), 851-863.

Yagci, M., Biswas, A., \& Dutta, S. (2009). Effects of comparative advertising format on consumer responses: The moderating effects of brand image and attribute relevance. Journal of Business Research, 62(8), 768-774.

Yadav, M. S., \& Varadarajan, R. (2005). Interactivity in the electronic marketplace: An exposition of the concept and implications for research. Journal of the Academy of Marketing Science, 33(4), 585-603.

Yoon, H. S., \& Lee, D. H. (2007). The exposure effect of unclicked banner advertisement. Cross Cultural Buyer Behavior, Advances in International Marketing, 18, 211-229.

Zhang, J., \& Mao, E. (2016). From online motivations to ad clicks and to behavioral 
intentions: An empirical study of consumer response to social media advertising. Psychology \& Marketing, 33(3), 155-164.
Zhang, X., \& Lin, W. (2014). Political participation in an unlikely place: How individuals engage in politics through social networking sites in China. International Journal of Communication, 8, 21-42.

\section{Attachment A - Scales used}

Perceived entertainment

Perceived entertainment was measured using a Likert scale (from $1=$ Totally disagree to 7 = Totally agree) of seven items:

The ad is witty and entertaining

The ad is creative

The ad not only sells the product, it entertains

The ad captivates

The ad is still in your mind after seen it

The ad captures your attention

The ad is fun

Attitude towards the brand

The attitude towards the brand was measured using a semantic differential scale ( 7 points or response categories) of four items:

Unpleasant - Pleasant

Boring - Interesting

Bad - Good

Unfriendly - Friendly

Intention to purchase

The intention to purchase the brand was measured by using a 7-point scale or response categories (from $1=$ very unlikely to buy Becker to 7 = very likely to buy Becker) ("If you had to buy beer the next time you go shopping, what is the likelihood that you will buy Becker as a result of the advertising you have just seen?")

\section{About the authors:}

1. Pablo Farías, PhD in Administration, University of Valladolid, Valladolid, Spain. Email: pfarias@fen.uchile.cl ORCIID

(D) 0000-0002-3120-8432

\section{Contribution of each author}

\begin{tabular}{lc}
\hline Contribution & Pablo Farías \\
\hline 1. Definition of research problem & $\sqrt{ }$ \\
2. Development of hypotheses or research questions ( empirical studies ) & $\sqrt{ }$ \\
3. Development of theoretical propositions ( theoretical Work) & $\sqrt{ }$ \\
4. Theoretical foundation/ Literature review & $\sqrt{ }$ \\
5. Definition of methodological procedures & $\sqrt{ }$ \\
6. Data collection & $\sqrt{ }$ \\
7. Statistical analysis & $\sqrt{ }$ \\
8. Analysis and interpretation of data & $\sqrt{ }$ \\
9. Critical revision of the manuscript & $\sqrt{ }$ \\
10. Manuscript Writing & $\sqrt{ }$ \\
\hline
\end{tabular}

